\title{
Cross-sectional Integration of the Water-energy Nexus in Brazil
}

\author{
Theodoros Semertzidis ${ }^{* 1}$, Catalina Spataru ${ }^{2}$, Raimund Bleischwitz ${ }^{3}$ \\ ${ }^{1}$ Institute for Sustainable Resources, University College London, 14 Upper Woburn Place, London, \\ United Kingdom \\ e-mail: t.semertzidis@ucl.ac.uk \\ ${ }^{2}$ Energy Institute, University College London, 14 Upper Woburn Place, London, United Kingdom \\ e-mail: c.spataru@ucl.ac.uk \\ ${ }^{3}$ Institute for Sustainable Resources, University College London, 14 Upper Woburn Place, London, \\ United Kingdom \\ e-mail: r.bleischwitz@ucl.ac.uk
}

Cite as: Semertzidis, T., Spataru, C., Bleischwitz, R., Cross-sectional Integration of the Water-energy Nexus in Brazil, J. sustain. dev. energy water environ. syst., 6(1), pp 114-128, 2018, DOI: http://dx.doi.org/10.13044/j.sdewes.d5.0169

\begin{abstract}
This paper analyses the cross-sectoral integration of the water-energy nexus in Brazil. Recent droughts resulted in unprecedented water scarcity. This caused water shortages for population and agriculture, as well as for electricity production (hydropower being the main source of electricity production). As a result, the system became more vulnerable to blackouts. To alleviate the problem, fossil fuels were used as a back up. Droughts, floods and other water-related problems will not dissipate as time goes by in Brazil. The dependency on one single predominant source (hydropower) makes Brazil's electricity supply vulnerable. This study shows through data analysis, flow diagrams and metrics the interrelation between water and energy. Based on historical data, the analysis shows the importance of the water demand for hydropower, cooling for thermal plants, and the extraction and production of biofuels, as well as of the energy demand of water services (water supply, wastewater treatment).
\end{abstract}

\section{KEYWORDS}

Water-energy nexus, Brazil, Resource flows, Metrics.

\section{INTRODUCTION}

Brazil recently faced its worst drought in 40 years. As a result, hydropower consumption fell by 7\% in 2013 and 5.5\% in 2014 [1]. In December 2014 the biggest dams were at only $16.1 \%$ capacity [2]. Population and the agriculture sector suffered due to the lack of water. Furthermore, cities were hit by blackouts due to weak hydroelectricity generation and high demand for services (e.g. use of air conditioning due to high temperatures). Burning more fossil fuels was one of the solutions to partly alleviate the problem. In the past years there were several droughts in Brazil and it is anticipated an increase in frequency and intensity, mainly in the Northeast of Brazil due to climate change [3]. Water availability in general is recognized to be an issue for Brazil. For the electricity sector this is alarming, taking into account that the hydroelectric production in Brazil accounts for more than $70 \%$ of the country's electricity supply

\footnotetext{
* Corresponding author
} 
matrix, with a current capacity of $91.348 \mathrm{GW}$. An additional $31.7 \mathrm{GW}$ is expected for the Brazilian hydropower sector in the northern region to match with the country's growing economy [4].

The population in the country has seen an increase of about $15 \%$ since 2000 [5]. Economic and social development invariably leads to urbanization and increased standards of living. In turn these changes require increased amounts of energy and water (among other resources). Climate change is affecting temperature and precipitation, which have an immediate effect on water resources and the energy industry in general, creating a vicious circle. More specifically, rising temperatures accelerate water movement, increasing both evaporation and precipitation. Also, there are falling average surface water flows, higher surface water temperatures, sea level rise that will contaminate freshwater supplies, and droughts, heat waves and floods that are more frequent and more severe [6].

Decreasing water availability directly impacts nearly all aspects of energy supply, and namely how electricity is produced, where future capacity might be sited, production cost, types of generation and cooling technologies and their costs, the methods and costs of extraction, production and delivery of fuels [7]. Particularly thermal plants with once-through cooling and hydropower can be exposed to fluctuations in water availability [8]. Bioenergy production can also be affected. As a consequence, in water scarce regions, competition for water between energy production and other uses will also increase, indirectly not allowing for economic development and stability [9].

In 2013, at the United Nations General Assembly [10] thematic debate, it was recognized that rain patterns and irrigation would play an important role for the reservoir management of hydropower and biofuels. As a consequence of these realizations, a ten-year energy plan considering alternative sources and energy efficiency stimulation was devised, taking into account competitiveness as well as social and economical viability.

This power policy mainly proposes a further hydropower expansion (mostly in the Amazon region) and future plants to be "run-of-the-river", with small or no reservoirs at all. This has caused problems on many levels, as the decisions to build large power plants are made long before consulting locals, which indicates a lack of nexus thinking in the planning process and leave the power supply system highly susceptible to events like droughts, which is recognised in recent work done for Brazil by Nogueira et al. [11] and Lucena et al. [12]. As of 2013, thermal power generation in Brazil, mostly fueled by natural gas and sugarcane bagasse, acts as a complementary source to hydropower, in an attempt to optimize the system's operation [11], which causes further concerns.

\section{LITERATURE REVIEW ON UNSOLVED ASPECTS OF THE PROBLEM}

There is general agreement in academia that research has not concentrated on the impacts of water availability on energy and more specifically the electric power sector, which is noticed in a variety of work done for example on the role thermal power plants with CCS may play in Brazil's future electric power generation [11], the energy sector's vulnerability to climate change [13], the impact of climate change on electricity systems and markets [14] and on the vulnerability of hydropower generation to climate change in China [15], with investigation only recently starting to take place. Also, the Water-Energy Nexus (WEN) from an engineering systems perspective has received little attention [16] and as Leck et al. [17] argue, the operationalisation of the WEN has to date been largely a paper exercise. At the technological level some studies optimize coupling points between electricity and water systems to reduce water and energy intensity of technologies, although models do not cover all sectors.

The main concern of most water models is to manage the distribution of water resources over space and time to meet specific objectives or demands. The energy 
supplies to divert, pump, and treat water is assumed to be adequate and in most cases the energy consumed in the different water demand scenarios is not quantified. This isolated assessment does not represent the dynamic relationship between water and energy. Also, water models typically have a high level of hydrologic detail (e.g. evapotranspiration, stream flows, return flows, exchange between surface and ground water) on particular watersheds, which makes them very data-intensive and complex. If a national water budget is to be assessed, the data intensity rises significantly [18].

Energy models are primarily concerned with siting and cost requirements for energy generation and transmitting the produced energy to population centres. Similarly to water models, energy models assume an existing supply of water necessary for power generation (with systems dominated by hydropower being an exception) and do not consider it to be a limiting factor in operations. Although energy models focus on generation, they do incorporate estimates of water demand for energy production through coefficients of water utilization per unit of output. What is missing is a consideration of water availability and its dynamic nature or trade-offs among water uses. Also, models do not consider the use of water to generate the electricity needed by water infrastructure. This could potentially be something negligible in regions with abundant supplies of water and energy, but important in the case of resource scarcity [18].

Apart from the aforementioned problems of both water and energy models, it is also difficult to integrate them. Energy and water models need to agree on spatial boundaries in order to be combined, since water models are primarily applied to watershed boundaries and energy models deal with political boundaries. This is one of the issues, when trying to combine such inherently different kinds of models. Some studies have successfully succeeded in this endeavor. This includes Karlberg et al. [19], Welsch et al. [20], Hermann et al. [21], Bartos and Chester [22], Dubreuil et al. [23], and Senger and Spataru [24]. The first three of these studies integrated WEAP and LEAP, while the last one added water and land components to an energy model.

Apart from the modeling issues mentioned above, another important issue is the aspect of metrics, especially since we are talking about a combined water-energy analysis. For example, Macknick et al. [25], Meldrum et al. [26] and BP [27], all stress out the fact that state agencies and reports fail to specify whether it is withdrawal or consumption that is being analyzed and do not use consistent methods or definitions in measuring water use by the energy sector. Healy et al. [28] argue that there is need to develop improved methods for measuring or estimating water withdrawal and consumption for energy use, especially in the case of hydroelectricity generation and biofuels production.

One important aspect of water metrics that is acceptably problematic in literature is the uncertainty in the consumptive water use of hydroelectric facilities. The main consumption comes from evaporation from large reservoirs, which though are multi-purpose, storing water for agriculture, industrial or domestic use as well as for power production [28]. Thus, the water losses cannot only be attributed to power generation purposes alone [29]. The consumption intensity depends on weather conditions and on the shape of the reservoir, and it can be higher than other power generation technologies, which is recognised by the International Energy Agency (IEA) [30], Mekonnen and Hoekstra's [31] work on water footprinting, and the Organisation for Economic Cooperation and Development (OECD) work on the economic impacts of the Land-Water-Energy Nexus [32]. Estimating these evaporative losses and attributing them to hydroelectricity or other uses is a major issue [33] and there is no commonly accepted methodology for it [34]. Also, apart from evaporation, there are other losses as well and namely seepage losses through the porous geology underlying hydroelectric reservoirs. According to Healy et al. [28] and Gleick [35], water lost through seepage, from the reservoir to the underlying groundwater system, is not considered consumed 
water because it is theoretically still available for use downstream, or it might recharge ground water resources.

What becomes clear when researching metrics is that there is a lack of consistency in the interpretation and use of different measures due to "a competition for the development of the 'correct' evaluation method" as Madani and Khatami [36] argue. These inconsistencies can create uncertainties and confusion to decision makers and academics, hindering the progress to more sustainable solutions that could solve emergent energy problems, without unintended impacts on water resources. Apart from the large number of measures, there are additional issues. Existing literature mainly assesses the amount of water withdrawn and consumed for energy production, showing a lot less interest in the evaluation of the effects of energy production to the quality and temperature of water.

\section{HYPOTHESIS AND PROPOSED METHODOLOGY}

The resource nexus is a framework attempting to integrate the crucial aspects of sustainable development. Only in the past few years has it been recognized as a way of dealing with resource issues and governments around the world are considering this. Essentially, the nexus concept recognizes linkages between resources. By unpicking relationships between these resources, it can help us appreciate how various sectors and industries could potentially achieve gains in resource efficiency and build their resilience against future challenges like shocks in resource availability of pricing [37].

The nexus, although a relatively easy concept to understand at first glance, is complicated and difficult to tackle. The main reason for this is that it needs to be looked at on many different scales and levels, from biophysical to political ones. The most direct linkages in the nexus exist at the resource level. Analysis of the biophysical impacts in space and time is vital to be undertaken in order to set the basis of the problem, which will further assist on the analysis on subsequent levels [37].

To achieve this, it is important to acknowledge for the drivers of change for the WEN and find the appropriate metrics for them. Subsequently, research the way and level to which water and energy resources are affected by the drivers, but also in relation to each other. Finally, it is important to also investigate the level to which the availability and also linkages of the two resources affect the different sectors (services). The first step to achieve these goals is to showcase the flows of water and energy from a resource level to end use and dissipation, while deciding on appropriate metrics. Following the quantification of the metrics and finding where the main linkages between water and energy occur, the outcomes of the flow analysis will be fed into the chosen modeling framework, in order to provide useful findings in terms of managing water constraints and develop an anticipation mechanism to deal with changes in water availability. The result of the modeling exercise should be able to suggest more strategically located power plants, implementing technologies that increase energy efficiency, and generally taking advantage of opportunities, like for example using wastewater as a potential source of energy.

There are three possible approaches to address the WEN in a modeling framework:

- Incorporate water resources and uses into an existing energy model;

- Incorporate energy production and uses into a water model;

- Or construct a combined framework.

The first option seems to be favoured over the other two due to the fact that energy systems models currently exist in many developing and emerging economies. It needs to be noted here that depending on one's perception of what it is that drives development as a whole, it is possible that the point of view as to which one of these options is the best choice would be different. The approach proposed in this research is to construct a water 
module inside an existing energy model, where the processes of the energy model would be spatially linked to the water supply locations from which they withdrew water.

The introduction of water into energy models would introduce new areas of uncertainty in the face of the variable nature of the underlying weather data projections (mainly precipitation and temperature) and their correlation to the energy service demand projections. Water models are frequently used to determine water systems' resilience to weather extremes, whether energy models are more frequently used to find economically optimal investments out of a vast number of options. Therefore, integrating water systems in energy modeling would require careful design of the input data sets [18].

\section{METRICS}

The metrics that should be used to address the issue are categorised into biophysical (which have to do with the environment), social and economic. It is always a good idea to start with the biophysical metrics, since it is vital to define the environment that is affected in each case, its capacity and limits.

\section{Biophysical}

Firstly, the general and geographical availability of resources need to be investigated. Then, water consumption and withdrawal data in all stages of energy production need to be either collected or calculated. The energy and water efficiencies of the available technologies and power plants need to be found, and also investigate if critical threshold values of specific energy technologies exist. Greenhouse Gas (GHG) emissions and other environmental impacts need to be taken into account. Quality and temperature of water before and after use would also be of importance, but data on these do not exist in Brazil. At the very least, the amount of wastewater is of great value for calculations. Also, dam data exists, but it does not specify usage by purpose, which is one thing that should be calculated, along with discharge patterns. Energy and water storage potential is also of importance, since it will help in times of droughts like the recent ones. Since Brazil is a big producer of ethanol, biofuel production and possible water needs in various scenarios should also be calculated.

Water use as a general term can be confusing. In engineering, water can be used in several functions in a process and each time this will be counted as a use, but this way the water used will be several times larger than the amount of water withdrawn. Water withdrawal, as the name implies, is a quantification of the amount of water removed from local sources temporarily, independent of its later use (energy production or processing, or other purposes). On the other hand, water consumption is the amount of water that is withdrawn but not returned to the local water basin from which it was abstracted. Consumed water is evaporated, transpired, incorporated into products or crops, or otherwise removed [27].

Water consumption is calculated in terms of water intensity, with the units being liters of water consumed per generated kilowatt-hour of electricity $(\mathrm{L} / \mathrm{kWh})$. The total water intensity of producing one kilowatt-hour of electricity is calculated according to Healy et al. [28] "by adding the water intensity for extracting and processing the fuel that is used in generating that electricity and the water intensity of the electrical power plant". Apart from water consumption, water withdrawal is also a key indicator for assessing water use in the energy sector and it is important to understand their difference. Also, since water is not uniformly distributed along Brazil, it could be useful to use the Water Scarcity Index (WSI) [38] to illustrate the extremes of regional variability. WSI is the annual freshwater withdrawal divided by the local renewable freshwater resource.

On the other hand, energy consumption is calculated in terms or energy intensity, with the units being kilowatt-hours of energy consumed per generated liter of water 
$(\mathrm{kWh} / \mathrm{L})$. Energy is consumed throughout the water cycle, and depending on the source of water and the distance and topography over which it is transported, it is possible that large amounts of energy are required to move water from its source to its final destination. The energy intensity of water treatment for example depends on the water source, quality of water, intended use and the chosen treatment process. The age of the water-treatment infrastructure could also affect energy intensity. Similarly, the energy intensity of groundwater pumping depends on pumping depth and the efficiency of the pump. The energy intensity of water conveyance is also dependent on the efficiency of the infrastructure. Leaks from unlined canals and pipelines can be substantial, as can evaporation from the open water surfaces of large reservoirs [28].

\section{Social and economic}

Biophysical metrics are more straightforward than social and economic metrics, although data availability can hinder their success. Starting with economic metrics, it is important to find the costs of the different technologies and their implementation. Furthermore, as mentioned earlier, the affluence and stability of the economy are drivers of change, and the Gross Domestic Product (GDP) has been the economic development indicator of choice for decades. The GDP can be used to measure growth, if this is assumed to be expansion of output of goods and services, because it was built for that purpose. At the same time though, it does not pay any attention to what, how or who is producing. Also, it does not show where the benefits go, how they are distributed. It does not necessarily show that a country is going at the "right direction", nor can it be used to capture human wellbeing. It is maybe inaccurate to say that is does not capture wellbeing in some degree, but it is only the wellbeing that results from the production of goods and services, missing out every other aspect of wellbeing. Taken on its own, GDP is an incomplete measure of a modern economy, and perhaps more attention needs to be given to other variables of growth and progress. Employment and salary rates, along with stability in all facets of an economy would be useful measures.

On the social aspect, since we have established that GDP is not a good measure for wellbeing, it is useful to investigate alternatives. The WEN, as all other aspects of the nexus, is not a static problem and it needs to account for a social/cultural context. One option would be the Human Development Index (HDI) [39] of the United Nations, which measures a nation's achievements in three dimensions, and namely long and healthy life, knowledge and decent standard of living. The problem with this one is that the last aspect is measured by GDP per capita, which as explained earlier is not representative. Then there are various happiness indices, which are slowly but steadily gaining attention. One of the most interesting ones is the Happy Planet Index (HPI) [40], which measures the ecological efficiency with which human wellbeing is delivered. Multiplying indices of life satisfaction and life expectancy and dividing by ecological footprint calculate it. Another interesting one is the Better Life Index (BLI) [41] by the OECD. It is an attempt to bring together internationally comparable measures of wellbeing, and it includes 11 dimensions and namely housing, income, jobs, community, education, environment, governance, health, life satisfaction, safety, and work-life balance. Each one of these topics is built using one to three specific indicators, giving an overall picture of a society.

\section{DATA ANALYSIS}

The data analysis is separated into energy and water sectors in Brazil, and water and energy intensities. The first part provides a picture of the two sectors in Brazil, and the second part provides literature estimates of water and energy intensities that are used in the majority of energy models. 


\section{Energy and water sectors analysis in Brazil}

The first step in analyzing the WEN in Brazil is to look at the energy and water sectors separately and identify the main points of interest at the biophysical level.

Figure 1 shows the main energy sources of Brazil and the process they go through. Water is used in the extraction/production and processing steps in various ways. In oil, water is used in drilling, hydraulic fracturing, water floods, steam heat, cooling, steam for turbines, and refinery. In biomass, water is used in irrigation of the crops, cooling, steam heat, steam for turbines and refinery. Natural gas uses water in drilling, hydraulic fracturing, cooling and steam for turbines. Coal uses water in drilling, irrigation, coal washing, dust suppression and cooling, cooling and steam for turbines. Uranium processes use water in drilling, dust suppression, uranium enrichment, cooling and steam for turbines. Hydro, wind and solar water uses are deemed negligible, although as explained earlier that is not true for hydro.

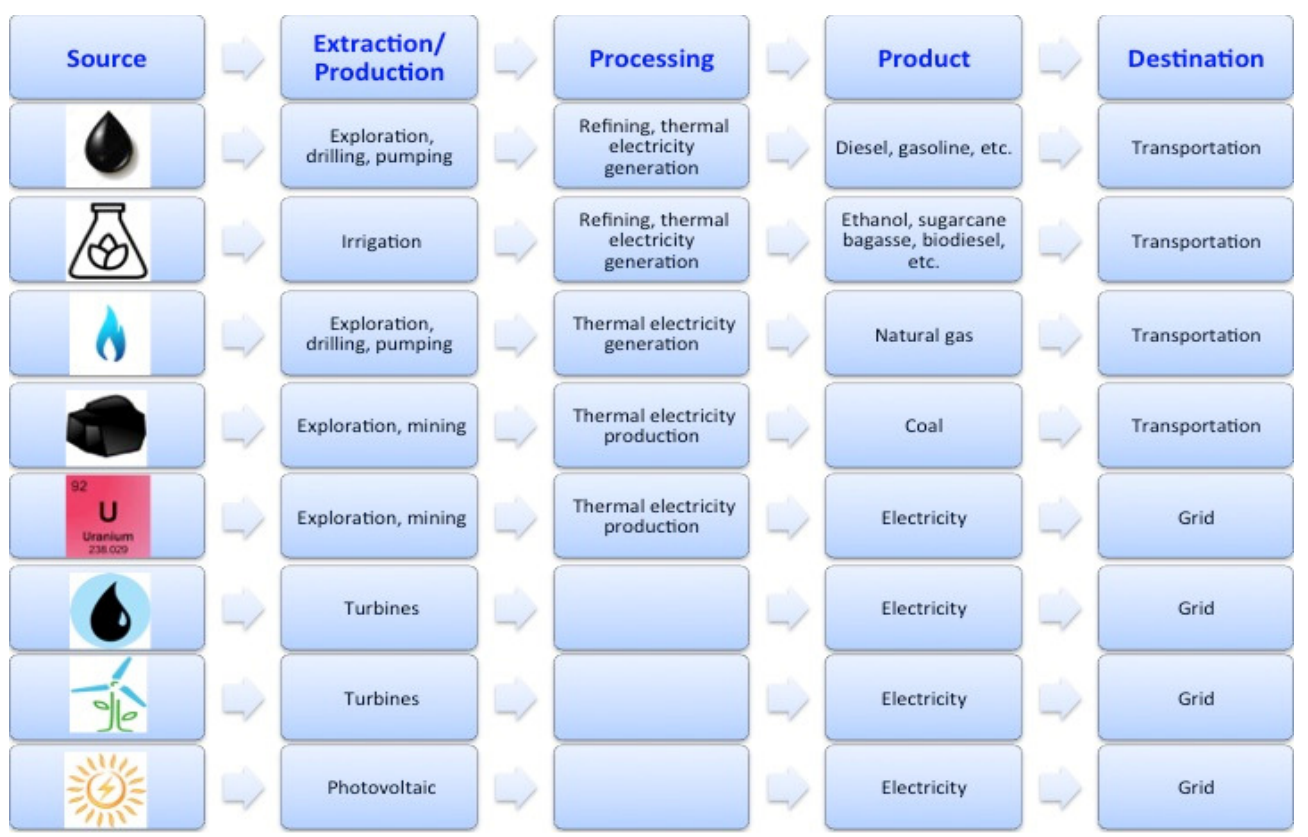

Figure 1. Energy pathways

In Figure 2, we show the flow of energy consumption in Brazil by source and sector for the year 2014. The total amount of energy consumed was 265,864 ktoe. By far the most important source of energy is oil products with $118,187 \mathrm{ktoe}$, from which most of it consists of gasoline and diesel oil for the transportation sector. In second place is electricity with 45,654 ktoe, with most of it going to the industrial and residential sectors. Also, in third place are the sugarcane products (ethyl alcohol and sugarcane bagasse) with 42,214 ktoe, with ethanol being used almost solely in the transportation sector and sugarcane bagasse being split between the energy and industrial sector. As a first step, the three aforementioned energy sources need to be investigated more closely. Also, looking at the diagram from the opposite side, we can see that most of the energy is consumed in the industrial and transportation sectors, followed by the energy and residential sectors. The electricity supply is presented more analytically in Figure 3, to further analyze the sources of electricity.

Most of Brazil's electricity is produced by hydroelectric power plants, followed by natural gas, biomass and oil products. The percentage of hydraulic energy supply has decreased in recent years, mainly due to increased overall demand and frequent droughts. Nonetheless, this percentage exceeds $60-65 \%$ on a constant basis and therefore is the first point that needs to be analyzed in the WEN. It is also important to investigate 
thermoelectric power plants and their efficiencies, since they have gained usage and also they are the ones where efficiency gains are more likely to take place.

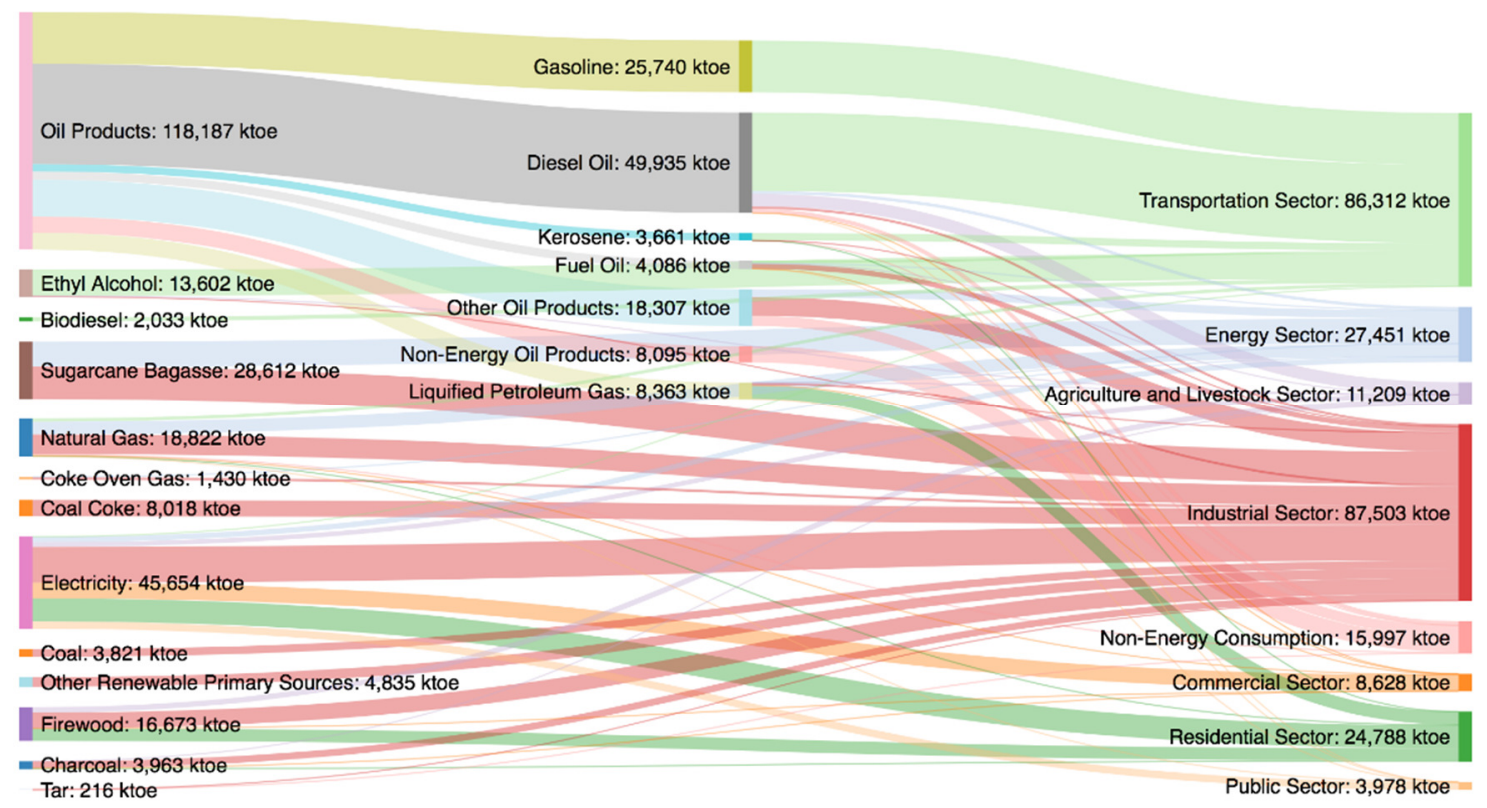

Figure 2. Energy consumption by source and sector in Brazil in 2014 (data source: [42])

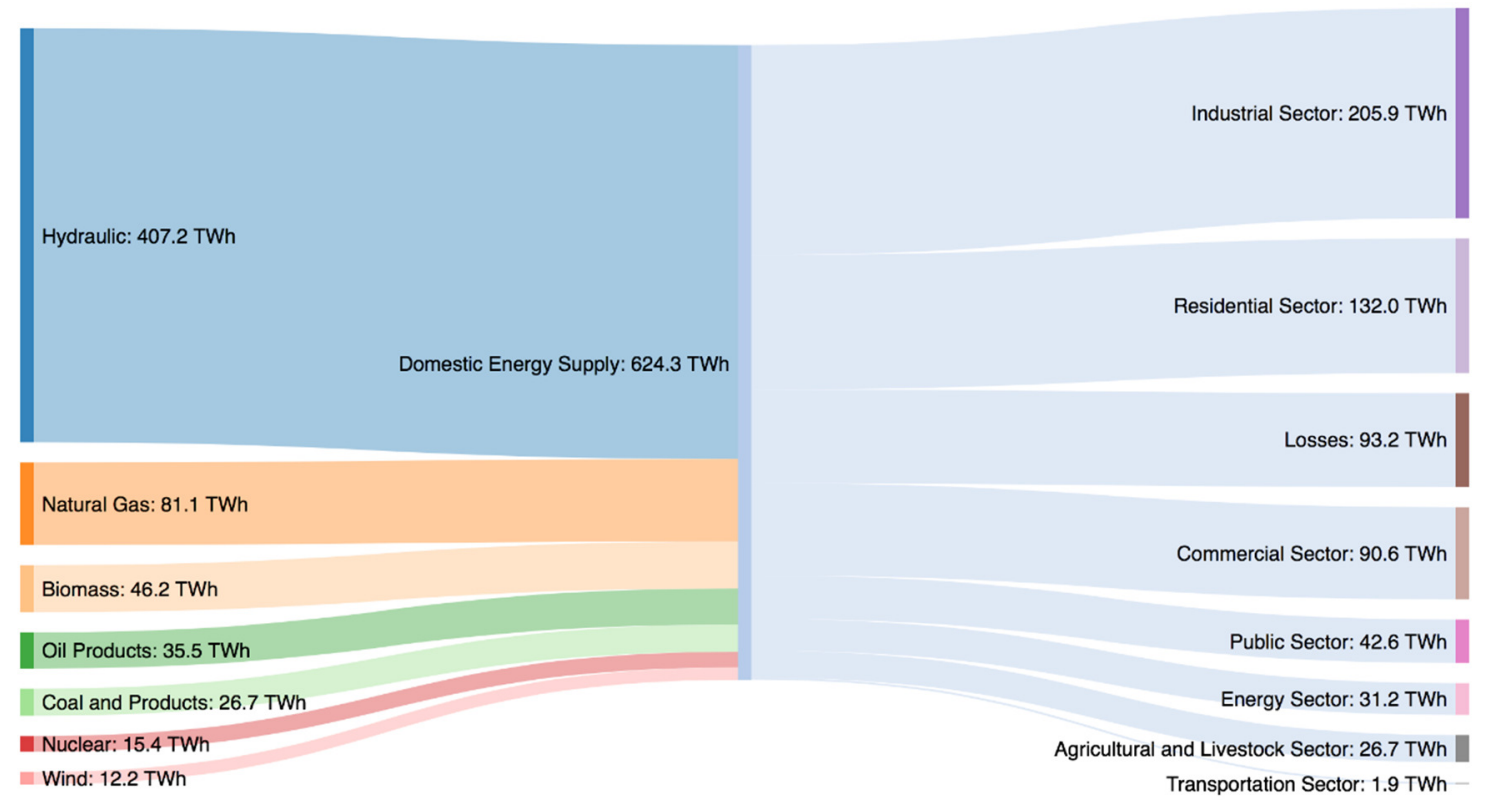

Figure 3. Domestic electricity supply in Brazil in 2014 (data source: [42])

In Table 1, we can see a comparison of final energy consumption by source for the most prominent sources in 2005 and 2014. Not surprisingly, due to an increase of population and living standards, there is also overall increased energy consumption by $26.5 \%$ within 10 years. The increase has been more or less uniform within these 10 years and keeping in mind that the population in Brazil is rising (although at a slow pace), and living standards along with the economy of the country will also potentially rise, we can see that so will the total energy demand and consumption of energy. All the main sources of energy saw a considerable increase, with ethyl alcohol doubling within 10 years. The only sources that saw a decrease (but are also not as important as others) are charcoal, fuel oil and naphtha. 
Table 1. Final energy consumption by sector (2005 and 2014) (data source: [42])

\begin{tabular}{cccc}
\hline Source & $2005[\mathrm{ktoe}]$ & $2014[\mathrm{ktoe}]$ & Change [\%] \\
\hline Natural gas & 13,410 & 18,822 & +28.8 \\
Firewood & 16,119 & 16,672 & +3.3 \\
Sugarcane bagasse & 21,147 & 28,612 & +26.1 \\
Electricity & 32,267 & 45,655 & +29.3 \\
Ethyl alcohol & 7,324 & 13,602 & +46.1 \\
Oil products & 83,954 & 118,186 & +29.0 \\
Diesel oil & 32,643 & 49,935 & +34.6 \\
Gasoline & 13,638 & 25,740 & +47.0 \\
\hline Total & 195,491 & 265,864 & +26.5 \\
\hline (including sources not in the list) & & &
\end{tabular}

Brazil is a vast country and resources are not evenly distributed. Table 2 is showing the population and the reserves of oil, natural gas and hydraulic potential divided in the five main geographical areas of Brazil. As we can see, most of the population is concentrated in the Southeast and Northeast of the country, by the Atlantic Ocean. The Southeast has predominantly oil and natural gas reserves, while the Northeast is at the opposite level. The Northeast seems to be more prone to disruptions in the future, since it also has the least hydraulic potential. Most of the hydraulic potential is concentrated in the North, which is understandably sparsely populated due to the existence of the Amazon River and forest. The North is where most of the planned hydroelectric plants are being built, due to the potential of the area.

Table 2. Proven reserves and hydraulic potential in 2014 (data sources: [5, 42])

\begin{tabular}{cccccc}
\hline & Population & $\begin{array}{c}\text { Oil } \\
{\left[10^{6} \mathrm{~m}^{3}\right]}\end{array}$ & $\begin{array}{c}\text { Natural gas } \\
{\left[10^{6} \mathrm{~m}^{3}\right]}\end{array}$ & $\begin{array}{c}\text { Hydraulic } \\
\text { potential }[\mathrm{MW}]\end{array}$ & $\begin{array}{c}\text { \% of hydraulic potential } \\
\text { being operated or being built }\end{array}$ \\
\hline North & $17,231,027$ & 13 & 52,383 & 100,370 & $31(19+12)$ \\
Northeast & $56,186,190$ & 146 & 45,329 & 22,102 & 52 \\
Southeast & $85,115,623$ & 2,414 & 373,383 & 43,757 & 59 \\
South & $29,016,114$ & 0 & 0 & 41,351 & 59 \\
Midwest & $15,219,608$ & 0 & 0 & 39,663 & $31(28+3)$ \\
\hline Brazil total & $202,768,562$ & 2,573 & 471,095 & 247,242 & $42(37+5)$ \\
\hline
\end{tabular}

Since the Southeast has most of the population, it is also the case that this is where most of the installed capacity of electrical generation exists, along with the oil refineries and gas plants, as seen in Table 3 .

Table 3. Installed capacity of electrical generation, oil refineries and natural gas plants in Brazil in 2014 (data source: [42])

\begin{tabular}{ccccccccc}
\hline & $\begin{array}{c}\text { Hydro Thermo } \\
{[\mathrm{MW}]}\end{array}$ & {$[\mathrm{MW}]$} & {$[\mathrm{MW}]$} & $\begin{array}{c}\text { Solar } \\
{[\mathrm{MW}]}\end{array}$ & $\begin{array}{c}\text { Nuclear } \\
{[\mathrm{MW}]}\end{array}$ & $\begin{array}{c}\text { Total } \\
{[\mathrm{MW}]}\end{array}$ & $\begin{array}{c}\text { Oil } \\
\text { refineries } \\
{\left[\mathrm{m}^{3} / \mathrm{day}\right]}\end{array}$ & $\begin{array}{c}\text { Natural gas plants } \\
{\left[10^{3} \mathrm{~m}^{3} / \mathrm{day}\right]}\end{array}$ \\
\hline North & 16,070 & 3,684 & 0 & 0 & 0 & 19,754 & 7,300 & 9,706 \\
Northeast & 11,553 & 9,530 & 3,904 & 7 & 0 & 24,993 & 79,353 & 24,500 \\
Southeast & 25,129 & 15,981 & 28 & 4 & 1,990 & 43,131 & 210,056 & 62,490 \\
South & 24,546 & 4,389 & 956 & 4 & 0 & 29,895 & 67,700 & 0 \\
Midwest & 11,895 & 4,244 & 0 & 0 & 0 & 16,139 & 0 & 0 \\
\hline Brazil total & 89,193 & 37,827 & 4,888 & 15 & 1,990 & 133,913 & 364,409 & 96,696 \\
\hline
\end{tabular}


The areas that have suffered the most from recent droughts and also the ones with a high chance of having disruptions of electricity and water are the most populated areas (Southeast and Northeast).

Table 4 shows the total and per capita consumption by geographic region. The Southeast is the most affluent one, followed by the South, which though does not have as much population as the Southeast. The Northeast on the other hand has the lowest per capita consumption, but at the same time, they have the least hydraulic potential and capacity, coupled with a very high population. This is most likely why the Northeast also has the most wind capacity in the country, since it needs to not solely depend on hydroelectricity, but have more varied options than other areas.

Table 4. Consumption by geographic region and per capita in Brazil in 2014 (data source: [43])

\begin{tabular}{ccc}
\hline & Consumption by geographic region [GWh] & {$[\mathrm{kWh} /$ capita] } \\
\hline North & 32,364 & 1,865 \\
Northeast & 80,746 & 1,432 \\
Southeast & 243,123 & 2,846 \\
South & 84,819 & 2,912 \\
Midwest & 34,381 & 2,243 \\
\hline Brazil & 475,432 & 2,630 \\
\hline
\end{tabular}

Table 5, shows the most "electricity hungry" sectors in Brazil. These are the industrial and residential, followed by the commercial sector.

After the analysis of the energy sector and seeing where investigation needs to be concentrated, it is vital to do the same with the water sector, in order to complete the WEN point of view. Water data in Brazil present two important problems. One of them is that the availability of data is very limited. Unlike the energy sector, where a lot of data is available, the main water agency in the country (ANA) does not have the funds nor consequently the capacity to produce detailed datasets. ANA produces a detailed report, alas with very little data, every four years (last one in 2013) and a smaller one every year (last one available in 2015). They do however have some useful data like the ones presented in the three following tables.

Table 5. Consumption by sector in Brazil in 2104 (data source: [43])

\begin{tabular}{ccc}
\hline & Consumption by sector [GWh] & {$[\%]$} \\
\hline Residential & 132,399 & 27.8 \\
Industrial & 179,618 & 37.8 \\
Commercial & 81,840 & 18.9 \\
Rural & 25,671 & 5.4 \\
Public sector & 15,354 & 3.2 \\
Public lighting & 14,043 & 3.0 \\
Public service & 15,242 & 3.2 \\
Own use & 3,265 & 0.7 \\
\hline Total & 475,432 \\
\hline
\end{tabular}

In Table 6 we can see that once again the Southeast has the highest water demand, as was the case with energy, followed by the Northeast and the South.

By looking at the water withdrawal and consumption data in Tables 7 and 8, we can see that the agricultural sector is the one that uses most of the water, most of it being consumed. This difference compared to other sector becomes even more significant when the withdrawal and consumption data for irrigation get added, as they are also in the energy data. Also, the urban water withdrawal is high. Although, it needs to be noted that there isn't an increasing trend here as it might have been expected. The same holds true 
for the industrial sector, where the withdrawal and consumption have not seen an increase from 2006 to 2014. This of course can in part be explained due to disruptions of water in dry seasons. Also, we can see that irrigation has seen an increased water consumption through the years, which potentially signifies that biofuel crops that are almost $100 \%$ rainfed need increasingly more irrigation.

Table 6. Regional water demand in Brazil in 2010 (data source: [44])

\begin{tabular}{ccc}
\hline & Regional water demand $\left[\mathrm{m}^{3} / \mathrm{s}\right]$ & {$[\%]$} \\
\hline North & 156.98 & 6.6 \\
Northeast & 604.08 & 25.5 \\
Southeast & 789.74 & 33.3 \\
South & 524.45 & 22.1 \\
Midwest & 297.58 & 12.5 \\
\hline Brazil total & $2,372.83$ & \\
\hline
\end{tabular}

Table 7. Total withdrawal of water in Brazil (data source: [44-46])

\begin{tabular}{ccccccc}
\hline & 2006 & & 2010 & 2014 & \\
\hline & $\begin{array}{c}\text { Total withdrawal } \\
\text { of water }\left[\mathrm{m}^{3} / \mathrm{s}\right]\end{array}$ & {$[\%]$} & $\begin{array}{c}\text { Total withdrawal } \\
\text { of water }\left[\mathrm{m}^{3} / \mathrm{s}\right]\end{array}$ & {$[\%]$} & $\begin{array}{c}\text { Total withdrawal } \\
\text { of water }\left[\mathrm{m}^{3} / \mathrm{s}\right]\end{array}$ & {$[\%]$} \\
\hline Industrial & 313 & 17 & 395 & 17 & 346.28 & 15 \\
Animal & 147 & 8 & 151.5 & 6 & 135.38 & 6 \\
Urban & 479 & 26 & 522 & 22 & 503.27 & 22 \\
Rural & 37 & 2 & 34.5 & 1 & 37.61 & 2 \\
Irrigation & 865.5 & 47 & 1,270 & 54 & $1,252.73$ & 55 \\
\hline Brazil total & 1,842 & & 2,373 & & $2,275.07$ & \\
\hline
\end{tabular}

Table 8. Total consumption of water in Brazil (data source: [44-46])

\begin{tabular}{ccccccc}
\hline & 2006 & \multicolumn{2}{c}{2010} & 2014 & \\
\hline & $\begin{array}{c}\text { Total consumption of } \\
\text { water }\left[\mathrm{m}^{3} / \mathrm{s}\right]\end{array}$ & {$[\%]$} & $\begin{array}{c}\text { Total consumption } \\
\text { of water }\left[\mathrm{m}^{3} / \mathrm{s}\right]\end{array}$ & {$[\%]$} & $\begin{array}{c}\text { Total consumption } \\
\text { of water }\left[\mathrm{m}^{3} / \mathrm{s}\right]\end{array}$ & {$[\%]$} \\
\hline Industrial & 69 & 7 & 78 & 7 & 69.26 & 6 \\
Animal & 118.4 & 12 & 125 & 11 & 108.30 & 9 \\
Urban & 98.7 & 10 & 104 & 9 & 100.65 & 8 \\
Rural & 19.8 & 2 & 18 & 1 & 18.80 & 2 \\
Irrigation & 680.5 & 69 & 836 & 72 & 912.63 & 75 \\
\hline Brazil total & 986 & & 1,161 & & $1,209.64$ & \\
\hline
\end{tabular}

\section{Water and energy intensities}

Although sugarcane crops are rainfed and thus it could be said that they do not require water in the production phase, if they do need to be irrigated due to lack of precipitation, the water intensity in the production phase can be quite significant as shown in Table 9.

Table 9. Sugarcane water use and withdrawal intensity (data source: [27])

\begin{tabular}{cccc}
\hline & $\begin{array}{c}\text { Average crop water use } \\
{\left[\mathrm{m}^{3} / \mathrm{ha} / \mathrm{yr}\right]}\end{array}$ & Average irrigation calculated & $\begin{array}{c}\text { Withdrawal intensity } \\
{\left[1,000 \mathrm{~m}^{3} / \mathrm{TJ}\right]}\end{array}$ \\
\hline Rainfed & 9,627 & 0 & 0 \\
Irrigated & 15,942 & 7,402 & 4.4 \\
\hline
\end{tabular}

Continuing with the production phase of energy production, Table 10 shows the averages of consumptive water intensities of different energy sources. The one that is the most intensive is unconventional oil, followed by coal. 
Table 10. Global average water intensity for energy production (data source: [27])

\begin{tabular}{cc}
\hline Sources & Average consumptive water intensity $\left[\mathrm{m}^{3} / \mathrm{TJ}\right]$ \\
\hline Conventional oil & 15 \\
Unconventional oil & 100 \\
Conventional natural gas & $<1$ \\
Unconventional natural gas & 17 \\
Coal & 40 \\
Uranium mining and processing & 2.5 \\
\hline
\end{tabular}

When it comes to the refining and conversion stages, as seen in Table 11, coal to liquids and ethanol conversion are the two most intensive ones. It needs to be noted that ethanol conversion also includes cooling for by-products electricity generation.

Table 11. Water intensity for refining and conversion (data source: [27])

\begin{tabular}{cc}
\hline Refining and conversion & Water intensity $\left[\mathrm{m}^{3} / \mathrm{TJ}\right]$ \\
\hline Crude oil refining & 16 \\
Gas processing & 0.7 \\
Gas-to-liquids & 18 \\
Coal-to-liquids & 300 \\
Ethanol conversion & 286 \\
\hline
\end{tabular}

Depending on the different technology of thermal power plants, the water intensities can also differ considerably. In Table 12 we can see averages of water intensities by cooling type. Despite the fact that the energy efficiency of the plants differs due to the cooling technology used, the water intensity considerably favours dry and once-through saline technologies.

Table 12. Freshwater intensity by cooling type (data source: [27])

\begin{tabular}{|c|c|c|c|c|c|c|}
\hline \multirow[b]{2}{*}{ Cooling type } & \multicolumn{2}{|c|}{ Coal } & \multicolumn{2}{|c|}{ Natural gas } & \multicolumn{2}{|c|}{ Nuclear } \\
\hline & $\begin{array}{l}\text { Withdrawn } \\
{\left[\mathrm{m}^{3} / \mathrm{TJ}\right]}\end{array}$ & $\begin{array}{c}\text { Consumed } \\
{\left[\mathrm{m}^{3} / \mathrm{TJ}\right]}\end{array}$ & $\begin{array}{l}\text { Withdrawn } \\
{\left[\mathrm{m}^{3} / \mathrm{TJ}\right]}\end{array}$ & $\begin{array}{c}\text { Consumed } \\
{\left[\mathrm{m}^{3} / \mathrm{TJ}\right]}\end{array}$ & $\begin{array}{c}\text { Withdrawn } \\
{\left[\mathrm{m}^{3} / \mathrm{TJ}\right]}\end{array}$ & $\begin{array}{c}\text { Consumed } \\
{\left[\mathrm{m}^{3} / \mathrm{TJ}\right]}\end{array}$ \\
\hline Dry & 60 & 60 & 3 & 3 & $\mathrm{n} / \mathrm{a}$ & $\mathrm{n} / \mathrm{a}$ \\
\hline Wet-tower & 640 & 540 & 260 & 220 & 790 & 660 \\
\hline $\begin{array}{l}\text { Once-through } \\
\text { saline }\end{array}$ & 60 & 60 & 3 & 3 & 3 & 3 \\
\hline $\begin{array}{c}\text { Once-through } \\
\text { fresh }\end{array}$ & 36,000 & 340 & 16,000 & 130 & 49,000 & 380 \\
\hline
\end{tabular}

Finally, Table 13 also showcases energy intensities to supply and treat water in different sectors, with the domestic sector being by far the most energy intensive and the industrial sector requiring the most energy for wastewater treatment.

Table 13. Energy intensities to supply and treat water in different sectors (data source: [27])

\begin{tabular}{cccc}
\hline Sector & $\begin{array}{c}\text { Supply from groundwater } \\
{\left[\mathrm{kWh} / \mathrm{m}^{3}\right]}\end{array}$ & $\begin{array}{c}\text { Supply from } \\
\text { surface water }\left[\mathrm{kWh} / \mathrm{m}^{3}\right]\end{array}$ & $\begin{array}{c}\text { Wastewater treatment } \\
{\left[\mathrm{kWh} / \mathrm{m}^{3}\right]}\end{array}$ \\
\hline Industrial & 0.198 & 0.079 & 0.661 \\
Domestic & 0.482 & 0.371 & 0.407 \\
Agriculture & 0.185 & 0.079 & $\mathrm{n} / \mathrm{a}$ \\
\hline
\end{tabular}




\section{CONCLUSION}

This paper is a first step into analyzing the WEN in Brazil. The country's electricity and water supply system is increasingly becoming vulnerable to climate change, which along with other drivers can magnify the problems. Something that is missing in dealing with water and energy issues is a consideration of water availability and its dynamic nature or tradeoffs among water uses. The resource nexus framework is suggested in this study, which recognizes linkages between resources. By unpicking relationships between these resources, it can help us appreciate how various sectors and industries could potentially achieve gains in resource efficiency and build their resilience against future challenges like shocks in resource availability of pricing. Various metrics important for the WEN are presented, mainly on the biophysical level, which is where the nexus first needs to be considered, but also at the social and economic levels, because they can by no means be left out of a nexus analysis, since they do include the main drivers of change. The data analysis part presents the energy and water sectors in Brazil, consumptions of energy by source and sector in the different geographical areas of the country, capacities, reserves and potential, water withdrawal and consumption. Finally, water and energy intensities from the extraction to the production of energy and treatment of water are presented. The goal of this study was to present the current situation in the water and energy sectors in Brazil and set the basis for developing a modeling framework to investigate the WEN in Brazil and thus limit uncertainties on issues of water that is available and the amount of water that is used in energy development. Provided that this uncertainty is reduced, predictions of future water and energy needs and availability can improve.

\section{REFERENCES}

1. BP, Statistical Review of World Energy, 2015.

2. Morales, A., Drought in US and Brazil Linked to Hottest Year Ever, Bloomberg New Energy Finance, 2014.

3. World Bank, Annual Report, 2013.

4. Westin, F. F., dos Santos, M. A. and Martins, I. D., Hydropower Expansion and Analysis of the use of Strategic and Integrated Environmental Assessment Tools in Brazil, Renewable and Sustainable Energy Reviews, Vol. 37, pp 750-761, 2014, http://doi.org/10.1016/j.rser.2014.04.071

5. IBGE, Projections and estimates of the Population of Brazil and of the Federation Units (in Portuguese), 2016, http://www.ibge.gov.br/apps/populacao/projecao/ notatecnica.html, [Accessed: 30-May-2016]

6. IPCC, Climate change and Water, 2008.

7. US Department of Energy, US Energy Sector Vulnerabilities to Climate Change and Extreme Weather, 2013.

8. IEA, Water for Energy (Excerpt from the World Energy Outlook 2012), 2012.

9. World Economic Forum, The Water-energy Nexus: Strategic Considerations for Energy Policy-makers, 2014.

10. United Nations General Assembly, Sustainable Development and Climate Change: Practical Solutions for the Water-Energy Nexus, 2013.

11. Nogueira, L. P. P., Lucena, A. F. P., Rathmann, R., Rochedo, P. R. R., Szklo, A. and Schaeffer, R., Will Thermal Power Plants with CCS Play a Role in Brazil's Future Electric Power Generation? International Journal of Greenhouse Gas Control, Vol. 24, pp 115-123, 2014, http://doi.org/10.1016/j.ijggc.2014.03.002

12. Lucena, A. F. P., Clarke, L., Schaeffer, R., Szklo, A., Rochedo, P. R. R., et al., Climate Policy Scenarios in Brazil: A Multi-model Comparison for Energy, Energy Economics, Vol. 56, pp 564-574, 2015, http://doi.org/10.1016/j.eneco.2015.02.005 
13. Schaeffer, R., Szklo, A. S., Lucena, A. F. P., Borba, B. S. M. C., Nogueira, L. P. P., et al., Energy Sector Vulnerability to Climate Change: A Review, Energy, Vol. 38, No. 1, pp 1-12, 2012, http://doi.org/10.1016/j.energy.2011.11.056

14. Chandramowli, S. N. and Felder, F. A., Impact of Climate change on Electricity Systems and Markets - A Review of Models and Forecasts, Sustainable Energy Technologies and Assessments, Vol. 5, pp 62-74, 2014, http://doi.org/10.1016/j.seta.2013.11.003

15. Wang, B., Liang, X. J., Zhang, H., Wang, L. and Wei, Y. M., Vulnerability of Hydropower Generation to Climate change in China: Results based on Grey Forecasting Model, Energy Policy, Vol. 65, pp 701-707, 2014, http://doi.org/10.1016/j.enpol.2013.10.002

16. Lubega, W. N. and Farid, A. M., Quantitative Engineering Systems modeling and analysis of the Energy-water Nexus, Applied Energy, Vol. 135, pp 142-157, 2014, http://doi.org/10.1016/j.apenergy.2014.07.101

17. Leck, H., Conway, D., Bradshaw, M. and Rees, J., Tracing the Water-energy-food Nexus: Description, Theory and Practice, Geography Compass, Vol. 9, No. 8, pp 445-460, 2015, https://doi.org/10.1111/gec3.12222

18. Rodriguez, D. J., Delgado, A., DeLaquil, P. and Sohns, A., Thirsty Energy, 2013.

19. Karlberg, L., Hoff, H., Amsalu, T., Andersson, K., Binnington, T., et al., Tackling Complexity: Understanding the Food-energy-environment Nexus in Ethiopia's Lake Tana Sub-basin, Water Alternatives, Vol. 8, No. 1, pp 710-734, 2015.

20. Welsch, M., Hermann, S., Howells, M., Rogner, H. H., Young, C., et al., Adding Value with CLEWS - Modelling the Energy System and its Interdependencies for Mauritius, Applied Energy, Vol. 113, pp 1434-1445, 2015, http://doi.org/10.1016/j.apenergy.2013.08.083

21. Hermann, S., Welsch, M., Segerstrom, R. S., Howells, M. I., Young, C., et al., Climate, Land, Energy and Water (CLEW) Interlinkages in Burkina Faso: An Analysis of Agricultural Intensification and Bioenergy Production, Natural Resources Forum, Vol. 36, pp 245-262, 2012, https://doi.org/10.1111/j.1477-8947.2012.01463.x

22. Bartos, M. D. and Chester, M. V., The Conservation Nexus: Valuing Independent Water and Energy Savings in Arizona, Environ. Sci. Technol., Vol. 48, No. 4, pp 2139-2149, 2014, https://doi.org/10.1021/es4033343

23. Dubreuil, A., Assoumou, E., Bouckaert, S., Selosse, S. and Maïzi, N., Water Modeling in an Energy Optimization Framework - The Water-scarce Middle East Context, Applied Energy, Vol. 101, pp 268-279, 2013, http://doi.org/10.1016/j.apenergy.2012.06.032

24. Senger, M. and Spataru, C., Water-Energy-Land Nexus - Modelling Long-term Scenarios for Brazil, $9^{\text {th }}$ IEEE European Modelling Symposium on Mathematical and Computer Simulation Madrid, IEEE Computer Society, Spain, 2015.

25. Macknick, J., Newmark, R., Heath, G. and Hallett, K. C., Operational Water Consumption and Withdrawal Factors for Electricity Generating Technologies: A Review of Existing Literature, Environ. Res. Lett., Vol. 7, No. 4, 2012.

26. Meldrum, J., Nettles-Anderson, S., Heath, G. and Macknick, J., Life Cycle Water use for Electricity Generation: A Review and Harmonization of Literature Estimates, Environ. Res. Lett., Vol. 8, No. 1, 2013.

27. Williams, E. D. and Simmons, J. E., BP Water in the Energy Industry, An Introduction, 2013, http://www.bp.com/energysustainabilitychallenge, [Accessed: 30-May-2016]

28. Healy, R. W., Alley, W. M., Engle, M. A., McMahon, P. B. and Bales, J. D., The Water-energy Nexus - An Earth Science Perspective, U.S. Geological Survey Circular, Vol. 1407, 107 p, 2015, http://dx.doi.org/10.3133/cir1407 
29. Siddiqi, A. and Anadon, L. D., The Water-energy Nexus in Middle East and North Africa, Energy Policy, Vol. 39, No. 8, pp 4529-4540, 2011, http://doi.org/10.1016/j.enpol.2011.04.023

30. IEA, World Energy Outlook, 2012.

31. Mekonnen, M. M. and Hoekstra, A. Y., The Blue Water Footprint of Electricity from Hydropower, Hydrol. Earth Syst. Sci., Vol. 16, pp 179-187, 2012, https://doi.org/10.5194/hess-16-179-2012

32. OECD/PBL, Economic Impacts of the Land-Water-Energy Nexus, 2015.

33. Dodder, R. S., A Review of Water use in the U.S. Electric Power Sector: Insights from Systems-level Perspectives, Current Opinion in Chemical Engineering, Vol. 5, pp 7-14, 2014, http://doi.org/10.1016/j.coche.2014.03.004

34. Bakken, T. H., Killingtveit, A., Engeland, K., Alfredsen, K. and Harby, A., Water Consumption from Hydropower Plants - Review of Published estimates and assessment of the Concept, Hydrologic and Earth Systems Science, Vol. 17, No. 10, pp 3983-4000, 2013, https://doi.org/10.5194/hess-17-3983-2013

35. Gleick, P. H., Water and Energy, Annu. Rev. Energy Environ., Vol. 19, pp 267-299, 1994.

36. Madani, K. and Khatami, S., Water for Energy: Inconsistent assessment Standards and Inability to Judge Properly, Curr. Sustainable Renewable Energy Rep., Vol. 2, No. 1, pp 10-16, 2015, https://doi.org/10.1007/s40518-014-0022-5

37. WWAP (United Nations World Water Assessment Programme), The United Nations World Water Development Report 2014: Water and Energy, Paris, UNESCO, 2014.

38. UNEP, Water Scarcity Index http://www.unep.org/dewa/vitalwater/article77.html, [Accessed: 30-May-2016]

39. UN, Human Development Index (HDI), http://hdr.undp.org/en/content/ human-development-index-hdi, [Accessed: 30-May-2016]

40. NEF, Happy Planet Index (HPI), http://www.happyplanetindex.org, [Accessed: 30-May-2016]

41. OECD, Better Life Index, http://www.oecdbetterlifeindex.org, [Accessed: 30-May-2016]

42. EPE, National Energy Balance 2015: Base Year 2014 (in Portuguese), 2015.

43. EPE, Statistical Yearbook of Electric Energy 2015: Base Year 2014 (in Portuguese), 2015.

44. ANA, Water Resources in Brazil: 2013 (in Portuguese), 2013.

45. ANA, Water Resources in Brazil: 2009 (in Portuguese), 2009.

46. ANA, Water Resources in Brazil: Report for 2015 (in Portuguese), 2015. 